\title{
Some Building Blocks for a Theory of the Firm as a Real Entity
}

\author{
David Gindis ${ }^{1}$
}

Published in Yuri Biondi, Arnaldo Canziani and Thierry Kirat (2007) (eds), The Firm as an Entity: Implications for Economics, Accounting and Law, London and New York: Routledge, 266-291

\section{INTRODUCTION}

The firm is a real entity and not an imaginary, fictitious or linguistic entity. This implies that the firm as a whole exhibits a sufficient degree of unity or cohesiveness and is durable and persistent through time. The firm is essentially composed of a particular combination of constituents that are bound together by something that acts as an "ontological glue," and is therefore non-reducible to other more basic entities, i.e., to its parts or its members. From our perspective, the firm is not simply an aggregate or a collection. It is a real integrated entity and a dynamic causal system. Institutional and organizational aspects enter the picture. These assertions stand in sharp contrast with mainstream theories of the firm whose proponents are more preoccupied with questions of contractual provisions, vertical integration or opportunism than the general and more fundamental questions related to what firms really are. 
The dominant contractual paradigm establishes the nature of the firm as a "nexus of contracts" (Jensen and Meckling, 1976) or a "collection of assets" (Hart and Moore, 1990), and further questioning of these constructs is left out of most, if not all, mainstream papers on the theory of the firm. When Cheung (1983: 3) claims that "we do not know what the firm is - nor is it vital to know," we are left with a simple "shorthand description" of a set of contractual relations. When Jensen and Meckling (1976: 311) brush off the question by stating that the firm is simply a "legal fiction," we are left with a "word" with as little substantive content as words referring to imaginary creatures. It is the object of this chapter to provide the theoretical grounds for rejecting these views. Firms are real entities that need to be theoretically treated as such.

The rest of the chapter is organized as follows. Section 2 establishes the main tenets and variations of the dominant theories of the firm before discussing some central problems related to the underlying ontological status of the firm. We claim that these views are so strong in denying the existence of the firm that they can hardly be said to be theories of the firm. Given that these theories are modern revivals of some old views, we revisit the turn-of-the-century debates in Section 3 in order to reconsider the merits of various alternative entity theories, adopting an analytical rather than historical perspective. Building on these insights, Section 4 provides some building blocks for a theory of the firm as a real entity. We argue that such a theory needs to overcome the impasse of reductionism and account for the firm's cohesiveness and durability through time. Finally, in Section 5, we discuss some implications of our analysis for the theory of the firm and apply some of our arguments to multi-unit structures such as corporate groups and vertical forms of network organization. 


\section{THE DOMINANT THEORIES OF THE FIRM IN ECONOMIC THEORY}

Our interest in this section lies mainly in synthesizing the "nexus of contracts" and "collection of assets" views of the firm, that are without a doubt the dominant views in economic theory. Arguably, the nexus of contracts view is also strongly established in corporate law theory. We therefore ignore other mainstream theories of the firm. We examine the underlying ontological status of the firm in the nexus of contracts and collection of assets views, and argue that both conceptions lack a meaningful theory of the nature of the firm. Their ontological individualism implies that anything other than individuals, their contractual relations and their assets is merely fantasy. This assessment paves the way for an alternative theory of the firm discussed in Sections 3 and 4.

\subsection{The Firm as a Nexus of Contracts}

The modern nexus of contracts theory of the firm goes back to Alchian and Demsetz (1972: 794) according to whom "the essence of the classical firm is ... a contractual structure." Picking up on this insight, Jensen and Meckling (1976: 310) agree that "contractual relations are the essence of the firm." In short, when "the firm is viewed as a set of contracts" (Fama, 1980: 289), it is not "vital to know" what the firm is since "the word 'firm' is simply a shorthand description of a way to organize activities under contractual arrangements" (Cheung, 1983: 3). In other words, "what is called a firm is a special set of contracts among owners of resources used in the coalition" (Alchian, 
1984: 34). Clearly, if the firm is seen as a "set of contracts," then the firm must also be seen as a set of individuals entering those explicit and implicit contracts.

The firm is thus conceptualized both as a set of contracts and as a "coalition" or an "association" between resources owners working more or less as a team. In fact, teamwork and contractual coalition arguably boil down to the same thing: "Does the essence of the 'firm' lie in teamwork or in the nexus of long-term contracts (i.e., agreements restraining the behavior of transactors)? ... Teamwork always involves such contracts. We ... can think of neither significant nor interesting cases where teamwork does not create dependencies calling for contractual restraints" (Alchian and Woodward, 1988: 70). Given that contracts restrain opportunistic individuals, contracts are the essential feature of the firm. Of course, given the ubiquity of contract, other forms of association as well as market transactions are said to be contractual.

Thus, contrary to Coase's (1937) theory of the firm-market dichotomy and Williamson's (1991) attempt to analyze “discrete forms,” Jensen and Meckling (1976: 311) state that "it makes little or no sense to try to distinguish those things that are 'inside' the firm ... from those things that are 'outside' of it." This makes sense from the nexus of contracts view, insofar as the world is regarded as a contractual continuum. Forms of economic organization differ only in degree since they all share the same contractual essence. Indeed, the contractual theory "makes the boundary of the firm fuzzy: a bright line distinguishing 'inside' and 'outside' is missing” (Alchian and Woodward, 1988: 76). On this conception of the world, "aspects of firm-like contractual arrangements brush aside the question of absolutes - 'When is a nexus of contracts $a$ 
firm?' - and substitute instead a question of relatives - 'When is a nexus of contracts more firm-like?'” (Demsetz, 1988: 155, emphasis in original).

Jensen and Meckling (1976: 310-311) stress that "it is important to recognize that most organizations are simply legal fictions which serve as a nexus for a set of contracting relationships among individuals ... The private corporation or firm is simply one form of legal fiction" (emphasis in original). Thus, when contractarians claim that the firm is the "common signatory of a group of contracts" (Hansmann, 1996: 18), they are referring to nothing more than a convenient "legal fiction," understood as "the artificial construct under the law which allows certain organizations to be treated as individuals" (Jensen and Meckling, 1976: 310, n.12). But in no sense should the firm be really viewed as such. Only individuals can have objective functions, can own and invest in assets, negotiate and sign contracts. It makes no sense to speak of the "behavior" of firms since firms are not individuals and only individuals can act, whether responsibly or not. ${ }^{2}$ It should be clear that "the 'personhood' of a corporation is a matter of convenience rather than reality" (Easterbrook and Fischel, 1991: 11).

In this context, Easterbrook and Fischel's (1985: 89) much-cited discussion of limited liability reminds us that "the liability of 'the corporation' is limited by the fact that the corporation is not real. It is no more than a name for a complex set of contracts among managers, workers, and contributors of capital. It has no existence independent of these relations." Whatever the expression used, i.e., "firm," "corporation," "nexus of contracts," or "legal person," for contractarians these are no more than shorthand ways of referring to individuals and their relations. Whether an "association" or a "coalition," the firm is the sum or aggregate of its individual members. In this sense, "it is not silly 
to consider the entry of a new stockholder to be the creation of a new firm" (Alchian, 1984: 47, emphasis in original). In dissolving the firm and dismissing it as a fiction, nexus of contracts theorists mean that shareholders own the corporate assets. ${ }^{3}$

\subsection{The Firm as a Collection of Non-Human Assets}

We now turn to the second mainstream conception of the firm according to which the firm is a collection of non-human assets. Our presentation of this approach is quite brief because the views of Grossman, Hart and Moore are simply stated when one has in mind the nexus of contracts point of view. Bluntly put, Grossman and Hart (1986: 693) "define a firm to consist of those assets that it owns or over which is has control." In this spirit, when looking for the firm in the web of contractual relations, the rule is simple: "identify a firm with the assets it possesses" (Hart and Moore, 1990: 1120). This property rights view of the firm excludes human assets or human capital since human assets are inalienable, i.e., cannot be bought or sold.

Such a statement of the nature of the firm as a collection of non-human assets contrasts with the nexus of contracts view, which "does less to resolve the questions of what a firm is than to shift the terms of the debate" (Hart, 1989: 1764). Here, the boundaries question is intimately linked to the nature of the firm question. Indeed, "one can ... sidestep the issue entirely, by arguing that everything is contractual, and that firms are a mirage [i.e., ] they are simply 'standard-form' contracts ... But if firms are a mirage, it is difficult to explain the enormous resources that firms expend merging and breaking up" (Moore, 1992: 494). Thus, property rights are essential to the theory of the 
firm since they provide an account of firm boundaries: assets that belong to the firm are "inside" firm boundaries and assets that do not are "outside."

In Hart and Moore's (1990) analysis, agents form coalitions depending on the expected value of their participation which in turn depends on the effects of asset ownership. However, whereas in the nexus of contracts view, the firm is the central contracting party and thus ensures the connection between the asset owners composing the coalition, in the theory of the firm as a collection of assets, the link is different. Since " a firm is identified with the collection of physical assets over which the owner ... has the residual control rights" (Moore, 1992: 496, emphasis in original), the link is the concentration of property rights in the hands of one agent. The coalition of owners disappears and we are left with "the owner" that personifies the aggregate of owners. What, then, is the link between the owner and the other agents necessary for production? The existence of such a link is a critical aspect of a theory of the firm and Hart (1995: 57) rightly underlines that "without something to hold the firm together, the firm is just a phantom." According to the theory of the firm as a collection of assets, the answer is obvious:

A firm's nonhuman assets ... simply represent the glue that keeps the firm together ... If such assets do not exist, then it is not clear what keeps the firm together ... One would expect firms without at least some significant nonhuman assets to be flimsy and unstable entities, constantly subject to the possibility of break-up or dissolution. My impression is that the (causal) evidence is not inconsistent with this view. (Hart, 1995: 57-59). 
The owner exercises control over nonhuman assets and this leads to an indirect control of human assets. The glue that ensures the link between human assets and the nonhuman assets, i.e., the firm, is thus one based on the exclusion and exit rights of the assets' owner: employers have considerable leverage by virtue of owning the nonhuman assets that workers need in order to be productive. We do not further develop the logic of the model since our interest lies in the nature of the firm. We pick up on the matter of the "glue" below.

\subsection{Underlying Ontological Commitments}

The preceding theories of the firm present some serious theoretical problems. Indeed, both views lack an adequate theory of the nature of the firm. In what follows, we make apparent the ontological commitments of these theories: either they make an outright denial of the existence of the firm, or they explain away the firm completely by concentrating on individuals. Commenting on the widespread adoption of the nexus of contracts view, Bratton (1989a: 409) writes: "some have accorded this notion the weight of scientific truth: It has been received in the legal literature as an ontological discovery with immediate and significant implications for corporate law discourse." Ironically, the "ontological discovery" is that the firm is a "fiction," i.e., that it does not really exist.

Jensen and Meckling (1976: 311) admit that the firm in their presentation has "little substantive content." There is no point to mark out "firm boundaries," since the concept itself makes little or no sense in a world that is a contractual continuum. The only possible difference between observed forms of organization is a difference in degree. There can be no differences in nature if the essence of everything is identical. 
The "firm" can be no more than the by-product of the study of contractual relations. This sort of reasoning is straightforward in denying the firm ontological status although it relies on notions of "firm-likeness" which beg a definition of the firm that should logically preexist. Fundamentally, the whole cannot be significantly different from the sum or aggregate of its parts. Indeed, if the firm does not exist apart in any way from its constituent parts, be these individuals, contracts and/or assets, then the issue of comparing the whole with the sum of the parts makes little sense.

A further problem of intellectual coherence can also be raised. If the world is a contractual continuum, which of the existing or possible contracts are those that define or belong to a particular firm? The reasoning cannot escape circularity since one cannot identify a nexus of contracts independently of a given firm. Surely, a firm cannot consist of all those contracts that are linked to the firm because that "would be like saying that a zebra is a nexus of stripes linked to a zebra" (Eisenberg, 1999: 830). The same is logically true of the collection of assets view of the firm that holds that a zebra is a collection of stripes owned by a zebra. Crucially, there is no essential difference, or difference in nature, between an individual owner of one asset and an individual owner of several assets, or between one asset and a set of assets. All individuals are owners of some assets. Are all individuals "firms"? Likewise, is any non-human asset a "firm"? To use Eisenberg's words again, it would be like saying that a zebra is a collection of stripes and that a one stripe is a zebra.

Can a "collection" of X count as the "nature" of Y? Hart (1995) needs a theory of something that can act as the "glue" because without it the firm is "just a phantom." Hart is correct. Without the glue, a "collection of assets" is no different from a heap of 
sand easily blown away on a windy day. Heaps of sand composed of random grains of sand are indeed "flimsy and unstable entities, constantly subject to the possibility of break-up or dissolution" (Hart, 1995: 58-59). Yet Hart's idea of the glue is poor. If "a firm's nonhuman assets ... simply represent the glue that keeps the firm together" (ibid.: 57), then the answer to the question "what is a firm?" is "a collection of nonhuman assets" and that the answer to the question "what holds the firm together?" is "a collection of non-human assets." Regardless of this logical problem, surely, the threat of exclusion alone cannot account for whatever holds the firm together and points more to the (potential) dissolution of the firm than to its (actual) unity. Far from being the sort of thing that could bind anything together, a collection is itself in need of being bound together if it is to form a whole.

Our critical assessment of the nexus of contracts and collection of assets stories thus reveals that these are in no meaningful sense theories of the nature of the firm. Therefore, both views cannot be said to be theories of the firm. Both are theories of "collections" of some sort and not of "firms." Words such as "firm" may be used in order to facilitate discussions with the layman or even with the specialist, but the word "firm" refers to sets of individuals, contracts and/or assets and is simply used for convenience. Firms exist only linguistically or conceptually. Firms are dissolved and dismissed as fictions. Contractual theorists in general and those cited in particular are ontological individualists. Anything can and everything should be reduced to individuals.

Firms do not act. Firms do not have intentions or objective functions. Their "behavior' is like the behavior of the market ... We seldom fall into the trap of 
characterizing the wheat or stock market as an individual, but we often make this error by thinking about organizations as if they were persons with motivations and intentions" (Jensen and Meckling, 1976: 50). This comparison with the impersonally efficient market is supposed to make economists think twice before ever again committing the error of thinking that the firm is an individual. However, to say that the firm is an "individual" is different from saying that it is a "person" in that the latter is a moral and legal term. Corporate personality may indeed be a legal fiction but individuality implies that firms may be said to distinctly exist and act in a unified sort of way - not that the corporation is an individual. This line of inquiry is important for our discussion throughout the rest of this chapter in which we seek to build an alternative theory of the firm as a real and not fictitious or linguistic entity.

\section{FROM FICTIONS AND AGGREGATES TO REAL ENTITIES}

We have argued that the nexus of contracts and collection of assets theories fail as theories of the nature of the firm. Given that both views are modern revivals of some old debates that have been evolving in a cyclical fashion for many centuries (Avi-Yonah and Sivan, this volume), a number of contemporary critics of current mainstream have called for the revival of the entity theory of the turn-of-the-twentieth-century (e.g., Blair, 1999; Smith, 2001). ${ }^{4}$ Reviving real entity theory is also our task in this section. Keeping in mind that "history offers ideas and approaches that are better and worse, and [that] the most recent is not always the best" (Smith, 2001: 72), instead of tackling the debate from a general historical perspective, we adopt an analytical perspective that seeks to disentangle the ontological from the normative aspects involved. We first 
underline the links between fiction, aggregate and property conceptions of the corporation before exploring the alternative entity view. ${ }^{5}$

\subsection{Fictions and Aggregates}

In most jurisdictions in the world, the corporation is a "legal person," a "legal entity" separate from the various natural persons composing it or having an interest in its economic activities. Legal personality means that the corporation can own assets, sign contracts, can sue or be sued, and so forth. However, under the doctrine of "piercing the corporate veil," courts may decide to break the legal protection offered by personality if the mask of separate personality is used fraudulently. In such cases, the law treats the corporation as a fiction and makes the natural persons involved liable for corporate torts or debts. This doctrine seems to imply that if we pierce the corporate veil, then we find nothing but real individuals. Many interpret this to mean that there was no real entity to begin with. While these issues have traditionally been applied to "corporations," they have been transposed to other types of "companies" by recent legal evolutions. ${ }^{6}$ Accordingly, although in this section we discuss the corporation following traditional debates, our arguments apply more generally to all forms of companies, i.e., to the firm.

As is well known, the "fiction theory of the corporation" is as old as Roman law and was often wielded by medieval canonists and civilists. The corporation was generally considered as an imaginary or legal being that could be nothing more than the individuals composing it. That this conception is closely linked to the "aggregate theory of the corporation" is quite obvious: since the corporation is nothing more than the aggregate of its real individual members, all reference to the collective corporate entity 
is reference to a "legal fiction" that is used merely for convenience. Proponents of this approach believed that "the rights and duties of an incorporated association are in reality the rights and duties of the persons who compose it, and not of an imaginary being" (Morawetz, 1882: 2). Jensen and Meckling (1976), and others, use both the fiction theory and the aggregate theory. Of the various possible aggregates, the aggregate of shareholders or owners may be called the "proprietary theory of the corporation." Hart's (1995) collection of assets view based on property rights is clearly a variant of this aggregate theory. In dissolving the firm and dismissing it as a fiction, contractarians declare that the aggregate of shareholders is the owner of the aggregate of corporate assets.

These views carry direct implications for the much-debated question of how firms should be run. Of course, following Jensen and Meckling (1976), Butler and Ribstein (1989) and Easterbrook and Fischel (1991), in a private property market economy, firms should be run in the exclusive or at least the predominant interest of shareholders. The only possible answer to Dodd's (1932) famous “For Whom Are Corporate Managers Trustees?" question is "the shareholders." Again, in dissolving the firm and dismissing it as a fiction, the basic agency model examines direct relations between the aggregate of shareholders and firm managers, the latter simply managing the former's assets. A popular rationale for this "shareholder primacy norm" is based on the belief that the category "shareholders" exhibits more homogeneous interests than any other "stakeholders" (e.g., Hansmann, 1996) and that shareholders, as residual claimants, are also the main risk-bearers in the undertaking of economic activities. 
However, Stauss (1944, reprinted in this volume) correctly criticized the mainstream myth of the existence of some unique class of individuals that are "homogenous risk-bearers" when in fact it is the firm as a whole that undertakes risky entrepreneurial activities. Arguably, shareholders, as defined by Hansmann, can themselves be considered "fictional," a category that the proprietary conception of the corporation needs in order to function. In fact, "shareholders ... are a legal fiction, and in many ways a far more problematic fiction than the corporation itself" (Greenwood, 1996: 1025). If the law is replete with fictions, what makes any one of them so special? The underlying ontological individualism of the dominant theory explains why shareholders are considered "more real" than corporations since corporations are said to exist only linguistically or conceptually. ${ }^{7}$

Many of those who today invoke the entity theory of some hundred years ago do so with the intent to influence the current corporate governance debate. Thus, entity sympathizers often remind us that managers legally owe fiduciary duty to the corporation itself rather than to the shareholders, that it is the corporation as a legal entity that owns corporate assets rather than the shareholders directly, and that no one owns the corporation (e.g., Blair, 1995; Greenwood, 1996; Iwai, 1999; Ireland, 1999; Stout, 2004). Alongside these explicit legal features against the dismissal of corporations as fictions, the more general "stakeholder theory of the corporation" (e.g., Donaldson and Preston, 1995) reminds us that individuals and groups of individuals other than shareholders are also part of the economic nexus and that running the firm in the sole interests of shareholder value is insufficient. In its crude version, stakeholder theory is a form of aggregate theory that simply denies the supremacy of the proprietary 
conception. In a more elaborate version, stakeholder theory views the corporation as a "social entity" or institution having social responsibilities.

Hence the general position of many proponents of corporate social responsibility today. Blair (1995) and Allen (2002) thus oppose two families of theories of the corporation, namely the "property theory of the corporation" which underlies the current shareholder primacy norm and the "social entity theory of the corporation." Although we share Blair's (1999) view that the entity theories of some hundred years ago need to be revived, we depart from the corporate governance and corporate social responsibility

debates and seek analytical insights for a theory of the firm only. ${ }^{8}$ We need to disentangle the ontological from the normative aspects of the real entity theory. We agree with Smith (2001: 71) who believes that "in the decades ahead, economists and legal scholars will become more sophisticated in their appreciation of human groups and of social forms such as corporations." This is precisely why we seek to provide some building blocks for a theory of the firm as a real entity. In what follows, we suggest the revival of entity theory through Freund's (1897) major but neglected work.

\subsection{Reviving Real Entity Theory}

The aggregate and fiction theories of the corporation of the turn-of-the-century were much criticized by authors influenced by Continental theories of "real corporate personality" associated with Hegelian legal theorists such as Gierke. Expressions such as "the personality of the corporation ... is in no sense ... artificial or fictitious, but is every whit as real and natural as is the personality of man" (Maitland, 1900: 335-36), or "a corporation is an entity - not imaginary or fictitious, but real, not artificial but 
natural" (Machen, 1911: 262) became quite common. As opposed to the fiction theory, the "real entity theory of the corporation," also called the "natural entity theory of the corporation," holds that the corporation not only exists separately from its members but also can literally be said to act and have "volition." As opposed to the proprietary theory, the corporation's being "person" implies that it cannot be considered an object of property rights.

Some entity theorists had larger preoccupations than the specific legal form of the corporation, extending their analysis to unincorporated bodies (Maitland, 1903) or to associations and partnerships, all seen as "more than the aggregate of [their] members" (Rowley, 1931: 560). From this point of view, the firm's existence has nothing to do with the law. The law simply complies with the fact of its existence and attributes legal capacity, i.e., recognition inside a particular legal system, to an already existing economic capacity, i.e., regardless of the legal system. Machen (1911: 261) thus states: "A corporation exists as an objectively real entity ... The law merely recognizes and gives legal effect to the existence of this entity. To confound legal recognition of existing facts with creation of facts is an error.” In the same spirit, Laski (1916: 422) claims that "the entities the law must recognise are those which act as such, for to act in unified fashion is - formality apart - to act as a corporation." In this sense, this movement was in search of a realistic approach regardless of legal form. ${ }^{9}$ Berle's (1947, reprinted in this volume) theory of "enterprise entity" as different from "corporate entity" is an important later contribution to this approach. 
In order to revive the entity theory, it is necessary to isolate these ontological aspects from the ever-present issue of corporate personality. Many entity theorists conflated "reality" and "naturalness" and accorded excessive weight to the "personality" of this natural entity. In fact, most debates and most of the confusion arose and still arise from the thorny issue of corporate personality. Therefore, given that corporate existence and corporate personality are all too often equated, this is the first issue that needs to be dealt with. We need to go beyond the fallacious assumption that if a collective entity is said to be treated in legal terms as a "legal person" this means that the collective entity is a person (Hodgson, 2002). Recall that Jensen and Meckling (1976) dismiss the firm as a fiction on the grounds that its personality is a fiction. Yet legal fictions need not be ontological fictions (Dejnožka, 2006). It is also important to note that what the law treats as "person" does not necessarily or effectively correspond to "human being" or "individual."

Fundamentally, the term "person" derives from the Latin persona and the Greek prosopa meaning "mask" in a dramatic representation. More precisely, "person” can refer to the mask worn by an actor, the actor behind the mask or the actor-in-the-mask. In his discussion of Vining's (1978) theory of "legal identity," Dejnožka (2006: 30) points out that "courts treat legal persons as human-beings-in-persons, corresponding to actors-in-masks. If [so], the legal persons are more than masks or roles. They are human beings in masks or roles. And a corporate person is a group of human beings in a collective mask or role." Such a collective mask is a social institution and this can be said without moral or normative intentions or preconceptions. What is behind the mask of legal identity is a real complex entity. This holds for all legal forms of business companies. 
Reviving entity theory also involves steering away from ideas of "organisms" and "groups souls" or "vital forces" that various entity theorists pronounced. It should be equally clear that our task is not to establish the "ultimate moral unit" sought by Maitland (1905) and many others. Rather, closer in spirit to Laski and Rowley, we need a causally grounded theory and not a morally grounded theory. Ontology is independent from and logically precedes the normative question. We are looking for a theory of the firm as "a relatively coherent and stable whole" since this is in effect our working definition of a real entity. In this context, Freund (1897) has had surprisingly few commentators, considering that his theory rejects the fiction and aggregate views of the corporation while avoiding the pitfalls of organicism and does not share the normative bent of other writers of his time.

Although speaking from the legalistic perspective, in an actually ontological and therefore morally neutral spirit, Freund (1897: 47) lists three "salient characteristics of the body corporate: its unity, its distinctiveness and its identity in succession." All three derive from a "representation principle" that is needed, according to Freund, in order to acknowledge the existence of higher-level rights and agency as opposed to individual rights and agency. In a nutshell, the representation principle is that corporate organization and corporate rules bind individual agency in such a way that one can properly speak of corporate unity, distinctiveness and retention of identity through change. For Freund, if these salient features are in fact present in a given association, one can speak of a real entity. The difficulty is to show how common purpose and collective action produce a level of unity, distinctiveness and identity sufficient for a corporation to be a real entity without appealing to any literally volitional or moral features. Freund says: 
The association becomes visible and active in and through

individuals only, but the common purpose, the concerted action, and the combined resources, produce upon our mind the impression, that the association itself enjoys something like the power of individual personal agency. The resulting conception is not one of absolute unity, such as the German jurists demand ... but a relative unity ... There is no absolute objective test by which we could be forced to allow or deny the character of unity to an aggregate body of human persons. The analogy of composite things explains perfectly the nature of the association. (Freund, 1897: 77)

Freund rightly insists on the unity of complex wholes composed of human and nonhuman integrated parts. His analysis analogizes corporations to composite artifacts. His theory of the reality of the whole as not literally an agent but as a causally interacting composite of agents and non-agents is consistent with the (literally false) phenomenological impression that the association itself enjoys the power of agency. Freund's three features of the corporation are what Rowley (1931) and much later Khalil (1997) called “individuality.” We prefer Freund's original terms. It is important to understand that this composite unity may be imperfect at times and that this is something that the law may or may not capture. The group's organization may or may not have the relative unity or wholeness that allows one to properly speak of collective action. 
The form and exercise of intra-association control are both essential elements of a theory of collective action. But while the power to act as a group is an essential element of the whole's reality, there is no need to suppose that there exists some sort of supraindividual or metaphysical "soul" or "vital force" of the corporation. In sum, Freund's (1897) approach paves the way for our analysis below which takes further theoretical steps. Stauss' (1944: 112, reprinted in this volume) subtle position is equally relevant as a point of departure of our own theory: "the entity known ... as the firm is taken as a real institution. As such the firm exists apart from the individuals who compose its decision-making organization, but it does not function apart from them. Thus the entity is not a fiction; it is a fact" (emphasis in original). Generally speaking, "the entity commonly known as 'corporate entity' takes its being from the reality of the underlying enterprise, formed or in formation" (Berle, 1947: 344, reprinted in this volume). This applies to all legal forms of business companies.

\section{BUILDING BLOCKS FOR A THEORY OF THE FIRM AS A REAL ENTITY}

Based on our preceding revival of entity theory through Freund's (1897) important work, our present task is to further develop a theory of the firm as a real entity. In the spirit of Weissman (2000), Mäki (2001) and Bunge (2003), we believe that economic ontology must include firms as fundamental wholes non-reducible to other more basic entities, i.e., to their parts or members. We argue that various forms of reductionism are untenable when theorizing firms and other complex human organizations. The firm as a real complex entity is at least as real as its members (Dejnožka, 2006). From an 
ontological point of view, the key issues are parts-whole relations, unity, wholeness, cohesiveness, persistence, durability, identity and distinctiveness. From an economic point of view, the directly related issues include collective action, institutions, organization, managed economic system, competence, knowledge stickiness and heterogeneity. From a legal point of view, the issues are substance over form or real enterprise over legal entity. In arguing against reductionism we provide a theory of the "ontological glue" that accounts for the firm's cohesiveness and durability through time.

\subsection{Beyond Reductionism}

Firms are not simply sets of contracts or collections of assets. The firm is not an epiphenomenon. To reduce the firm to its constituent parts "is no more reasonable than is treating a human being as no more than the chemicals that make her up" (Greenwood, 2005: 15). Although mereological relations, i.e., complex parts-whole processes, need to be part of a theory of the firm, we reject "mereological essentialism" (Chisholm, 1973) that holds that parts are essential to their wholes in the sense that the whole is determined by the parts. This is a typically reductionist position since the whole does not exist independently of its parts and any modification of the parts implies a modification of the whole. Clearly, the aggregate theories discussed throughout this chapter, and in particular Alchian's (1984: 47, emphasis in original) view that "it is not silly to consider the entry of a new stockholder to be the creation of a new firm," are strictly speaking compatible with mereological essentialism. This presents a conceptual problem for the identity or durability of the whole through time. 
Firms are not aggregates or "mereological sums." The very issue of comparing the whole to the sum of its parts is problematic. In his discussion of the problem, Copeland (1927) rightly stresses that for parts or whatever to be summed together they need to be of the same magnitude. For example, how does one "add" individuals and non-human assets or artifacts? Addressing this question, Ruben (1983) argues that individuals cannot be said to be "parts" of social wholes since "being a part of" is a purely mereological relation whereas when we think of individuals as "members" of such wholes we have in mind a particular social relation not reducible to mereological relations. While we can think of non-human assets or artifacts as "parts" of firms, we need to admit the theoretical superiority of individuals as "members" of firms or other organizations since this connotes the members' agential power through which firms function. In any case, the whole is reducible neither to its members (e.g., owners) nor to its parts (e.g., assets).

The fact that reductionism fails as an adequate analysis of the nature of the firm implies that if one systematically reduces the firm as a whole to anything else one necessarily loses sight of a great deal of the picture. It is important to stress that firms as structured wholes compete with other firms as structured wholes, that firms as wholes can sue and be sued (even though individuals go to court as actors-in-the-mask), can produce and be competitive. Firms as wholes possess capabilities. Firms as wholes have temporal reputations in transactions and generate income or suffer losses. Firms as wholes undertake risk-bearing activities (Stauss, 1944, reprinted in this volume). There is nothing imaginary or fictitious about these facts. Actually, casual observation as well as many legal and accounting features support these claims. In accordance with Freund (1897), unity, distinctiveness and identity through succession allow one to properly 
speak of collective capabilities, firm competitiveness, identity and reputation, and so on, as real properties of the firm as a real entity. Sets of contracts and collections of assets simply do not have any of these properties. ${ }^{10}$

It follows that the theory of the firm cannot exclude certain important "holistic" aspects. This does not imply any form of determinism or collectivism that annihilates individual agency, since wholes do not fully determine their parts and members any more than parts and members fully determine wholes. It simply means that certain structural, functional and systemic considerations need to enter the picture. Indeed, "a system ... is ... a complex thing whose components are bound together, as a consequence of which the whole has peculiar properties and behaves as a unit in some respects" (Bunge, 2000: 148). Such "emergent properties" are properties of the whole not reducible to properties of its constituents. Given that emergence is by definition a bottom-up relation between ontological levels, it is fully relevant to the theory of the firm as a real entity. ${ }^{11}$

Importantly, emergence entails novelty. As a causal process, emergence accounts for new properties at the emergent level. Therefore, we need to understand the crucial and complex links between emergent entities and their properties and lower-level entities and their properties. In this respect, what does it mean to say that the higher level entity is real? For one, this implies that it is persistent: "emergents appear as integrated wholes that tend to maintain some sense of identity over time" (Goldstein, 1999: 50). For another, it implies that this higher level has some sort of causal power. Emergent levels exert some form of "downward causation" (see Emmeche et al., 2000) or a form of "reconstitutive downward causation" (Hodgson, 2003) that partly mold 
lower levels by giving shape and purpose to the interacting constituents. Again, this does not mean that higher levels fully determine lower levels but that this complex twoway causality of what may be termed "constitutive dynamics" is part of the "ontological glue" that keeps the whole together.

We may summarize our position with Dejnožka's (2006) reminder that existence is power for Plato: power to cause, power to stay unified, power to avoid dissolution. Fictitious or conceptual entities do not have such causal powers. For Leibniz, the stronger the unity or wholeness, the more real the entity. The stronger the unity or the cohesiveness of the whole, the more we move from random sets to real entities (French, 1982; Copp, 1984; Tuomela, 1989; Dejnožka, 2006). In this sense, simple aggregates or random sums are to be distinguished from entities that deserve to be considered "real." One may thus properly distinguish "aggregates" from "social integrates" (e.g., Pettit, 2003; Copp, 2006). Aggregates simply do not have any of the properties of real entities. Given these ontological considerations, we reject the fiction theory that eliminates the reality of the firm as a whole and we reject the aggregate theory that reduces the whole to some of its members or parts.

\subsection{Cohesiveness and Durability through Time}

From a theoretical point of view, firms as wholes have human members and non-human parts arranged into a complex structure or interactive system. By adding precision to the central concept of the "glue" that holds parts and members together as a cohesive whole, our discussion stresses that unity, wholeness and cohesiveness as well as identity and durability through time are essential ingredients of a theory of real entities. In his 
search for new foundations, Zingales (2000) feels that these issues are important but the ontology involved remains atomistic. An important point that reductionists miss is that once a certain cohesion and unity is attained, group behavior is not identical or reducible to the behaviors of its elements. In fact, "groups may be cohesive, which individuals cannot be, and cohesiveness may affect the stability of the group, which is again something individuals ... cannot have" (Brodbeck, 1958: 16). Cohesion and unity can properly be said to be properties of the firm.

From our perspective, a theory of the firm as a real entity needs to include some notion of "ontological glue" understood here as being at least in part a form of efficient causation (in Aristotle's terms), i.e., as the complex system of upward causation and reconstitutive downward causation. Weissman (2000) appositely speaks of "causal reciprocity." We also need to include "teleological glue" as a form of final causation (again, in Aristotle's terms) manifested among other things by collective purpose and forward-looking behavior. The firm's collective action capacity is reinforced by: “institutional glue" provided both by formal and informal rules, and by habits and routines; "organizational glue" manifested by structures, processes, functions and roles; "motivational glue" that ensures adherence to the common goal; "cognitive glue" accounting for shared beliefs and representations; and, finally, "productive synergy glue" or "competence glue" which relates to the complex co-specialization of human assets such as knowledge and non-human assets. All these blends of glue contribute to the firm's cohesion and organize the collective action of its members, that is, the firm's relative behavioral unity through time. The more the emergent whole is unified or integrated, the more it can and should be considered a real entity. 
Ontological individualism is based on the commonplace that collective entities such as firms cannot exist without any individuals. Yet the firm's persistence through time, based on the replication of behavioral patterns and collective routines, implies that any particular firm continues to exist even if all its present human constituents are progressively replaced. Such independence qualifies the firm as a real entity: "economic entities ... actually have reality, in the sense that they are patterns which exist independently of their parts" (Raby, 1959: 460). Our discussion fits a crucial empirical and theoretical insight from the evolutionary theory of the firm, namely that collective knowledge is typically "sticky" and that collective competence is retained through progressive change in firm membership. If this were not the case, the firm would certainly be a flimsy entity, incapable of survival in an evolutionary setting and thus incapable of preventing dissolution. Indeed, in terms of the "units of selection" debate in evolutionary economics, "group selection operates when the individuals in the group are bound together in a sufficiently cohesive manner to share a mostly common fate" (Hodgson and Knudsen, 2004: 300). ${ }^{12}$

Ideas similar to those presented here can be found in the literature. For instance, Langlois and Foss (1997: 213) argue that firms are not held together by the "thin glue of transaction-cost minimization, but rather by the thicker glue of capabilities." Kay (2000: 704) considers that "[the] glue is likely to be found in complex strategic decisions made by the firm." Likewise, philosophers such as Pettit (2003) and Copp (2006) demonstrate that some groups typically "collectivize reason" in many complex decision-making situations and that this institutionalization may act as a glue. We can thus properly speak of "integrates" as opposed to "aggregates." Finally, Commons (1924) and Raby 
(1959) both insist on what may be called a "working rules glue" combined with "expectational glue" characteristic of any "going concern":

That which holds the going concern together is [a set] of working rules affording an expectation of a gross income to be obtained jointly ... If the expectation fails, the immortality fails. When the expectation continues, the corporation is a 'going concern.' For this reason, the legal form is subordinate. (Commons, 1924: 145).

It is the real, ongoing collective dynamics of activity bound together by forward-looking behavior patterns that is the basis of many of the real entity's properties and causal powers manifested by its economic process. Although legal form is subordinate to economic substance, as real entity theorists correctly stressed, it is important to understand the role played more generally by institutions, considering that the "circular, positive feedback from institutions to individuals and from individuals to institutions can help enhance the durability of the institutional unit" (Hodgson, 2003: 172).

\subsection{Institutions and Individuals}

Institutions are both constraints and resources for individuals. Institutions both depend on individuals and channel individuals' behavior. Institutions depend on real acts, and are real because of these acts. In this respect, the problem of structure and agency (Swanson, 1992; Archer, 1995; Lawson, 2003; Hodgson, 2004) is an ontologically crucial one for social science in general and economic theory in particular. Our arguments in this chapter are in line with this literature's fundamental insight that social reality is composed of something more than and is non-reducible to individuals. 
Structure is a product of, a constraint on and a resource for individual and collective agency. One can properly speak of embodied institutional reality. Thus, in her ontology of institutional kinds, Thomasson (2003: 605) writes: "although they do not meet the [strong] realist paradigm of entities entirely independent of us for their existence and essence, they certainly are also not mere mental constructs." The firm as a real institution exists independently of its individual members but does not function apart from them.

In order to function, the firm relies on the structured dynamics of real acts of individuals and groups of individuals. In fact, internal organization of authority and competence allows one to attribute "secondary actions" to collective entities such as firms via "primary actions" of their individual members in specific corporate positions (Copp, 1979). In other words, corporations "act" through their internal decision structure (French, 1982). From a different perspective, Searle's (1995) “constitutive rule" that "X counts as $\mathrm{Y}$ in context $\mathrm{C}$ " can be directly applied to individual and collective action: action $\mathrm{X}$ of corporate officer $x$ counts as action $\mathrm{Y}$ of the firm because of $x$ 's corporate position. Any consequent problem that may arise is therefore that of the firm as a whole as long as $x$ acted in accordance with the "business judgment rule" or any other such rule. There are, therefore, ways of legally and conceptually attributing actions directly to the firm without "personifying" or "hypostatizing" the firm. The firm "acts" not literally but institutionally through actors-in-the-mask. This is similar to Freund's (1897) representation principle that links individual agency to collective agency. 
More fundamentally for our discussion, as a real economic entity, the firm is an organization comprising human members and non-human parts that can be seen as an active "managed economic system” (MacMillan and Farmer, 1979; Biondi, 2005). Inside firms, humans typically engage in various activities the composite outcomes of which constitute what may properly be said to be the firm's particular productive activities. Intra-firm organizational and institutional structure is the complex combination of typically rule-based, goal-intended and forward-looking behavior. Although collective routines ensure the replication of outcomes, the replication is imperfect and this possibility, among others, introduces variation and heterogeneity in both organizational and productive outcomes. Accordingly, the need to maintain relative behavioral unity between different periods of time is essential to the firm's coherence. Hence, commitment to a common goal or undertaking is crucial in order for the relative behavioral unity to emerge and persist through time.

It is important to recognize that people do things together and that people inside firms and other organizations reason in terms of "we" and "they" (Simon, 2002). Such "identification is a powerful force ... by virtue of the loyalty it can produce to the goals of the whole system" (Simon, 1991: 41, reprinted in this volume). The firm's identity is an emergent cognitive property that certainly has causal powers of reconstitutive downward causation. The possibility of conflicts or power struggles and other incentive compatibility problems does not change our theoretical analysis of the nature of the firm as a real complex and active whole in significant ways. In fact, our analysis amplifies the importance of institutions in achieving the relative behavioral unity of collective action allowing the firm as a whole to attain its intended goals even though these may change or be betrayed. 
When we say that what holds the firm together is a combination of a variety of types of glue, we do not mean to imply that all firms are identical in their actual unity. Building up this unity is a dynamic and temporal process and the stronger the cohesiveness or wholeness the more real the entity. Our view is thus compatible with Biondi's (2005) concept of “becoming concern." Following Simon's (1996) discussion of complexity, artificiality and emergence, firms function and survive in their environment because they are examples of "adaptive artifice." Given this complexity, it is impossible to agree with Jensen and Meckling's (1976: 50) view that the "behavior" of the firm is like the behavior of the market" since the concept of "equilibrium" cannot apply to the firm as a whole (Biondi, 2005). The firm is not some "spontaneous order" guided by an "invisible hand."

We follow Dejnožka's (2006) important ontological discussion in concluding that firms as real entities are both "interactive systems" and "complex artifacts." As interactive systems, firms function through the agential power of their members. As artifacts, firms typically exhibit purposive design and institutionalized functional unity. When we say that firms are artifacts, we do not imply that they can be reduced to instruments in the hands of shareholders or of any other constituents, or that their design is flawless. We simply mean that they are non-natural entities that are a product of human design and deliberate action. The members' agential power, or the deliberate determination of people to make their firm succeed, given certain goals and rules of action, is necessarily part of the ontological glue that accounts for the firm's cohesiveness and durability through time. Adopting a non-reducitionist view on the nature of the firm does not eliminate individual agency. The contrary is quite true. 


\section{IMPLICATIONS AND APPLICATIONS}

We have theoretically outlined what it means to say that the firm is not a fiction, legal or otherwise, but a real entity that typically exhibits a relative degree of cohesiveness and durability through time. The entity is real in that it possesses causal power to resist dissolution - not mechanically, but through the agential power of its ongoing human constituents, whose real actions are organized and to some extent institutionalized. The firm's ontological glue is causal, teleological, institutional, organizational, motivational, cognitive, expectational, and productive- or competence-based. The overall result is the coherence and continuity of the whole which can no longer be viewed as reducible to any of its constituent parts or members. It follows that reductionism and more generally ontological individualism lead to a failure of the theory of the firm and of other social organizations. The nexus of contracts and collection of assets theories of the firm fail in their account of the firm on the grounds provided throughout this chapter. Our discussion carries several implications for current debates regarding the theory of the firm as well as some direct applications to group regulation.

\subsection{Implications for the Theory of the Firm}

The theory of the firm is traditionally taken to be about three questions: the existence and nature of the firm (although these are two different questions); the boundaries of the firm; and the internal organization of the firm. We believe that our account of the nature of the firm sheds new light on what should properly be considered a fourth question of a theory of the firm, namely the question of firm heterogeneity. Indeed, talk of the firm's distinctiveness, identity or individuality implies this fourth question. Our account of the 
cohesiveness and wholeness of the firm also relates to the second sense of the term “individuality": relative indivisibility or, put differently, relative non-decomposability. This does not mean that economic analysis should never take a closer look at particular constituents or relations. We are not denying that contracts are relevant for the theory of the firm. What it does mean, however, is that the whole should not be forgotten or explained systematically away.

Methodological individualism, as a monist doctrine of the "unique" or "ultimate" mode of analysis, fails if applied systematically. Many aspects of the firm such as competence and knowledge that rightly should be part of a theory of the firm are collective or holistic in nature. Ignoring them has contributed to the failure of the mainstream theory of the firm. In his discussion of the current debate between the contractual and the competence theories of the firm, Williamson (1999: 1102) writes: the "troublesome argument is that of aggregation. Taking a more holistic view, the firm as a whole is different from and larger than the sum of the parts ... Inasmuch as transaction cost economics purports to be interested in all regularities whatsoever, it stands to benefit from research in the competence tradition on holistic consequences." Although we have not discussed the transaction cost economics theory of the firm as a “governance structure," Williamson's point applies in general to all contractual theories that hold that the contract or the transaction is the basic unit of analysis.

In line with a growing recent literature, we consider that combining the more holistic competence perspective with the contractual approach is one of the main challenges awaiting the theory of the firm (see Weinstein, this volume). Gibbons (2005: 238) has expressed this view under the heading "breaking loose." The contractual 
approach generally examines isolated transactions such as given "make-or-buy" situations, ignoring the link between this specific transaction and all other economic activities of the firm. On the other hand, the competence perspective insists on firms as non-reducible dynamic wholes. As such, the firm is a productive entity, a "competent team" (Eliasson, 1990) and a "knowledge-creating entity" (Nonaka, Toyama and Nagata, 2000). It is as a whole that the firm is competitive or not. Both levels of individual incentives and contracts, and of collective knowledge, learning and competence, need to enter the picture. The question of combining the two perspectives on the theory of the firm is a fundamentally ontological undertaking that relies on the recognition that reality is multi-layered. By providing an account of the causal reciprocity between levels, our analysis of the cohesiveness and durability of the firm through time reinforces the relevance for the theory of the firm of the evolutionary ontology developed in the "units of selection" debate (e.g., Hodgson and Knudsen, 2004).

In order to further explain the heterogeneity of firms, the approach needs to rely on both universal and historically specific concepts and these need to be coherently articulated (Hodgson, 1998). We have argued that unity, cohesiveness and durability through time of a complex combination of members and parts are the ontological features of the firm as a real entity. This ontological skeleton needs to receive economic, legal and accounting flesh, i.e., be contextualized in terms of particular economic, legal or accounting attributes a specific firm has. The particular constellation of intra-firm and extra-firm relationships characterizing each given firm depends on historical circumstances (Chandler, 1992). We believe that our general theory of the firm as an economic entity is logically compatible with the observed varieties of capitalism, since 
it admits indefinitely many blends and varieties of teleological, institutional and organizational unity. The particular type of legal entity a given firm happens to be provides form only, the substance of the firm being independent of legal artifice.

\subsection{Applications to Integrated Multi-Unit Structures}

Our general view according to which the stronger the unity or cohesiveness or wholeness, the more real the entity, has direct applications to integrated multi-unit structures such as business groups and vertical forms of network organization, both from a theoretical point of view and from the point of view of regulation. Blumberg (1990b, 1993) has argued at length that "enterprise law" should apply to complex structures such as corporate groups, meaning that law should not systematically place form over substance or legal entity over real enterprise (see Berle 1947, reprinted in this volume, and Manfrin, this volume). Indeed, applied directly, corporate law tends to see multiple entities instead of one whole economic enterprise. However, in terms of liabilities against outsiders such as tort victims or final consumers, such multi-unit structures need to be treated as single economic wholes. For Deakin (2003), the very idea of "enterprise risk" needs to be reconsidered in the light of these complex structures. In fact, Deakin argues, a general move towards "organizational liability" within tort law is needed. The implicit ontological commitment underlying these views is very different from the fiction and aggregate theories discussed in this chapter, since for contractarians such as Easterbrook and Fischel (1985: 89), "the liability of "the corporation' is limited by the fact that the corporation is not real." By the same token, a corporate group is presumably not real from this point of view. 
The implications of our real entity theory are clear in relation to this problem. Internal legal independence between subsidiaries should not blind us to the fact that these complex structures are complex artifacts designed to compete collectively with other such enterprises as wholes. The fact that each unit composing the structure may or may not be pursuing other objectives does not change the analysis. In the same spirit, Orts (1998) has argued that what he calls "relational firms," i.e., those complex structures that maintain internal legal autonomy while remaining more or less cohesive economic units, should legally be treated accordingly, depending on the question at hand. For Orts (1998: 313), "whether a relational firm is considered one entity or a group of entities will depend ... on the question that is asked ... If the question is whether a relational firm is acting as a unit in competing with other firms in markets, the answer will focus on the lines of authority that enable it to act as a single entity."

Blumberg's corporate groups are just one form of Orts' relational firms, one in which equity participation and controlling interest in subsidiaries are a major feature of the parts-whole relationships. Corporate groups, conglomerates and holding companies all share this feature in different degrees and for different purposes, varying from majority to minority ownership structures. The question of applying our arguments to multi-unit forms of economic organization that do not involve equity ownership is even more challenging. We have, in fact, applied some of the arguments of this chapter to vertical forms of network organization in which a "hub-firm" or "vertical architect firm" organizes production between legally independent entities (Baudry and Gindis, 2005). In accordance with Orts, we argued that the hub-firm's power to control the network as a whole and to prevent its dissolution implies that a vertical network form of this sort may properly be treated as a single economic entity. 
In all these interactive complex systems, be they single firms, business groups or vertical network forms of organization, the bottom line is that the stronger the unity and durability of action, the more real the economic entity, regardless of formal legal structure. The whole can be (and is) held together by the various forms of glue we have described and it seems trivial to state that such wholes often thrive by competing with each other. 


\section{REFERENCES}

Alchian, Armen A. (1984), "Specificity, Specialization and Coalitions," Journal of Institutional and Theoretical Economics, 140(1): 34-49.

Alchian, Armen A. and Demsetz, Harold (1972), "Production, Information Costs and Economic Organization,” American Economic Review, 62(5): 777-795.

Alchian, Armen A. and Woodward, Susan (1988), “The Firm Is Dead; Long Live The Firm: A Review of Oliver E. Williamson's The Economic Institutions of Capitalism," Journal of Economic Literature, 26(1): 65-79.

Allen, William T. (1992), "Our Schizophrenic Conception of the Business Corporation," Cardozo Law Review, 14(2): 261-281.

Archer, Margaret S. (1995), Realist Social Theory: The Morphogenetic Approach, Cambridge: Cambridge University Press.

Baudry, Bernard and Gindis, David (2005), “The V-Network Form: Economic Organization and the Theory of the Firm," unpublished, U. Lyon 2. Available online at <http://ssrn.com/abstract=795244>.

Berle, Adolf A. (1947), “The Theory of Enterprise Entity,” Columbia Law Review, 47(3): 343-358. Reprinted in this volume.

Biondi, Yuri (2005), “The Firm as an Entity: Management, Organisation, Accounting," paper $\mathrm{n}^{\circ} 46$, $\mathrm{U}$. Brescia. Available online at $<$ http://ssrn.com/abstract=774764>.

Blackwell, Thomas F. (1999), “The Revolution Is Here: The Promise of a Unified Business Entity Code," Journal of Corporation Law, 24(2): 333-378.

Blair, Margaret M. (1995), Ownership and Control: Rethinking Corporate Governance for the Twenty-First Century, Washington D.C.: Brookings Institution Press.

Blair, Margaret M. (1999), "Firm-Specific Human Capital and Theories of the Firm," in Blair, Margaret M. and Roe, Marc J. (eds), Employees and Corporate Governance, Washington D.C.: Brookings Institution Press. 
Blumberg, Phillip I. (1990a), "The Corporate Personality in American Law: A Summary Review," American Journal of Comparative Law, 38(S): 49-69.

Blumberg, Phillip I. (1990b), "The Corporate Entity in an Era of Multinational Corporations," Delaware Journal of Corporate Law, 15(2): 283-375.

Blumberg, Phillip I. (1993), The Multinational Challenge to Corporation Law: The Search for a New Corporate Personality, New York: Oxford University Press.

Bratton, William W. (1989a), “The 'Nexus-of-Contracts' Corporation: A Critical Appraisal," Cornell Law Review, 74(2): 407-465.

Bratton, William W. (1989b), “The New Economic Theory of the Firm: Critical Perspectives from History," Stanford Law Review, 41(6): 1471-1527.

Brodbeck, May (1958), "Methodological Individualisms: Definition and Reduction," Philosophy of Science, 25(1): 1-22.

Buchanan, James M. (1988), “Contractarian Political Economy and Constitutional Interpretation," American Economic Review, 78(2): 135-139.

Bunge, Mario (2000), “Ten Modes of Individualism - None of Which Works - And Their Alternatives," Philosophy of the Social Sciences, 30(3): 384-406.

Bunge, Mario (2003), Emergence and Convergence: Qualitative Novelty and the Unity of Knowledge, Toronto: University of Toronto Press.

Butler, Henry N. and Ribstein, Larry E. (1989), “The Contract Clause and the Corporation," Brooklyn Law Review, 55(4): 767-808.

Chandler, Alfred D. (1992), "What Is a Firm? A Historical Perspective," European Journal of Economics, 36(2-3): 483-492.

Cheung, Steven N. S. (1983), "The Contractual Nature of the Firm,” Journal of Law and Economics, 26(1): 1-21.

Chisholm, Roderick M. (1973), "Parts as Essential to Their Wholes," Review of Metaphysics, 26(4): 581-603.

Coase, Ronald H. (1937), “The Nature of the Firm,” Economica n.s., 4(16): 386-405. 
Cohen, Felix S. (1935), "Transcendental Nonsense and the Functional Approach," Columbia Law Review, 35(6): 809-849.

Commons, John R. (1924), Legal Foundations of Capitalism, New York: Macmillan. Reprinted: 1995, New Brunswick, NJ: Transaction Publishers.

Copeland, Morris A. (1927), “An Instrumental View of the Part-Whole Relation," Journal of Philosophy, 24(4): 96-104.

Copp, David (1979), “Collective Actions and Secondary Actions,” American Philosophical Quarterly, 16(3): 177-186.

Copp, David (1984), "What Collectives Are: Agency, Individualism and Legal Theory," Dialogue, 23(2): 249-269.

Copp, David (2006), “On the Agency of Certain Collective Entities: An Argument from 'Normative Autonomy'," Midwest Studies in Philosophy, 30: 194-221.

Deakin, Simon (2003), “"Enterprise-Risk': The Juridical Nature of the Firm Revisited,” Industrial Law Journal, 32(2): 97-113.

Dejnožka, Jan (2006), Corporate Entity, unpublished book manuscript. Available online at <http://www.members.tripod.com/ Jan_Dejnozka/corporate_entity_book.pdf >.

Demsetz, Harold (1988), “The Theory of the Firm Revisited," Journal of Law, Economics and Organization, 4(1): 141-161.

Dodd, E. Merrick (1932), “For Whom Are Corporate Managers Trustees?” Harvard Law Review, 45(7): 1145-1163.

Donaldson, Thomas and Preston, Lee E. (1995), "The Stakeholder Theory of the Corporation: Concepts, Evidence and Implications," Academy of Management Review, 20(1): 65-91.

Eisenberg, Melvin A. (1999), "The Conception That the Corporation is a Nexus of Contracts and the Dual Nature of the Firm," Journal of Corporation Law, 24(4): 819-836.

Easterbrook, Frank H. and Fischel, Daniel R. (1985), "Limited Liability and the Corporation," University of Chicago Law Review, 52(1): 89-117. 
Easterbrook, Frank H. and Fischel, Daniel R. (1991), The Economic Structure of Corporate Law, Cambridge, MA: Harvard University Press.

Eliasson, Gunnar (1990), “The Firm as a Competent Team,” Journal of Economic Behavior and Organization, 13(3): 275-298.

Emmeche, Claus, Køppe, Simon and Stjernfelt, Frederik (2000), "Levels, Emergence and Three Versions of Downward Causation," in Anderson, Peter B., Emmeche, Claus, Finnemann, Niels O. and Christiansen, Peder V. (eds), Downward Causation: Minds, Bodies and Matter, Arhus: Arhus University Press.

Fama, Eugene F. (1980), "Agency Problems and the Theory of the Firm," Journal of Political Economy, 88(2): 288-307.

Foster, Nicholas H. D. (2000), "Company Law Theory in Comparative Perspective: England and France," American Journal of Comparative Law, 48(4): 573-621.

French, Peter A. (1982), “Crowds and Corporations,” American Philosophical Quarterly, 19(3): 271-277.

Freund, Ernst (1897), The Legal Nature of Corporations, Chicago, IL: Chicago University Press.

Friedman, Milton (1970), “The Social Responsibility of Business Is to Increase Its Profits," New York Times Magazine, September 13.

Gibbons, Robert (2005), "Four Formal(izable) Theories of the Firm?” Journal of Economic Behavior and Organization, 58(2): 200-245.

Goldstein, Jeffrey (1999), “Emergence as a Construct: History and Issues,” Emergence, 1(1): 49-72.

Greenwood, Daniel J. H. (1996), "Fictional Shareholders: For Whom Are Corporate Managers Trustees Revisited," Southern California Law Review, 69(5): 10211104.

Greenwood, Daniel J. H. (2005), "Introduction to the Metaphors of Corporate Law," Seattle Journal for Social Justice, 4(1): 1-31.

Grossman, Sanford and Hart, Oliver D. (1986), "The Costs and Benefits of Ownership: 
A Theory of Vertical and Lateral Integration," Journal of Political Economy, 94(2): 691-719.

Hager, Mark M. (1989), "Bodies Politic: The Progressive History of Organizational 'Real Entity' Theory,” University of Pittsburgh Law Review, 50(3): 575-654.

Hansmann, Henry (1996), The Ownership of Enterprise, Cambridge, MA: Harvard University Press.

Hart, Oliver D. (1989), “An Economist's Perspective on the Theory of the Firm," Columbia Law Review, 89(7): 1757-1774.

Hart, Oliver D. (1995), Firms, Contracts and Financial Structure, New York: Oxford University Press.

Hart, Oliver D. (2001), "Norms and the Theory of the Firm," University of Pennsylvania Law Review, 149(6): 1701-1715.

Hart, Oliver D. and Moore, John (1990), "Property Rights and the Nature of the Firm," Journal of Political Economy, 98(6): 1119-1158.

Hodgson, Geoffrey M. (1998), "The Coasean Tangle: The Nature of the Firm and the Problem of Historical Specificity," in Medema, Steven G. (ed.), Coasean Economics: Law and Economics and the New Institutional Economics, Boston, MA: Kluwer.

Hodgson, Geoffrey M. (2002), “The Legal Nature of the Firm and the Myth of the Firm-Market Hybrid," International Journal of the Economics of Business, 9(1): 36-60.

Hodgson, Geoffrey M. (2003), "The Hidden Persuaders: Institutions and Individuals in Economic Theory," Cambridge Journal of Economics, 27(2): 159-175.

Hodgson, Geoffrey M. (2004), The Evolution of Institutional Economics: Agency, Structure and Darwinism in American Institutionalism, London: Routledge.

Hodgson, Geoffrey M. and Knudsen, Thorbjørn (2004), “The Firm as an Interactor: Firms as Vehicles for Habits and Routines," Journal of Evolutionary Economics, 14(2): 281-307. 
Horwitz, Morton J. (1992), The Transformation of American Law, 1870-1960: The Crisis of Legal Orthodoxy, New York: Oxford University Press.

Hovenkamp, Herbert (1988), "The Classical Corporation in American Legal Thought," Georgetown Law Journal, 76(5): 1593-1689.

Humphreys, Paul (1997), "Emergence, Not Supervenience," Philosophy of Science, 64(S): S337-S345.

Ireland, Paddy (1999), "Company Law and the Myth of Shareholder Ownership," Modern Law Review, 52(1): 32-57.

Israels, Carlos L. (1952), "The Sacred Cow of Corporate Existence: Problems of Deadlock and Dissolution," University of Chicago Law Review, 19(4): 778793.

Iwai, Katsuhito (1999), "Persons, Things and Corporations: The Corporate Personality Controversy and Comparative Corporate Governance," American Journal of Comparative Law, 47(4): 583-632.

Jensen, Michael C. and Meckling, William (1976), "Theory of the Firm: Managerial Behavior, Agency Costs and Capital Structure," Journal of Financial Economics, 3(4): 305-360.

Jensen, Michael C. (2002), "Value Maximization, Stakeholder Theory and the Corporate Objective Function," Business Ethics Quarterly, 12(2): 235-256.

Kay, Neil M. (2000), "Searching for the Firm: The Role of Decision in the Economics of Organization," Industrial and Corporate Change, 9(4): 683-707.

Khalil, Elias L. (1996), "Is the Firm an Individual?" Cambridge Journal of Economics, 21(4): 519-544.

Kincaid, Harold (1995), “The Empirical Presuppositions of Metaphysical Explanations in Economics," Monist, 78(3): 368-385. Reprinted in Mäki, Uskali (2001) (ed.), The Economic World View: Studies in the Ontology of Economics, Cambridge: Cambridge University Press. 
Langlois, Richard N. and Foss, Nicolai J. (1997), "Capabilities and Governance: The Rebirth of Production in the Theory of Economic Organization," Kyklos, 52(2): 201-218.

Laski, Harold J. (1916), “The Personality of Associations,” Harvard Law Review, 29(4): 404-426.

Lawson, Tony (2003), Reorienting Economics, London: Routledge.

Litowitz, Douglas (2005), "The Corporation as God,” Journal of Corporation Law, 30(3): 501-538.

Machen, Arthur W. (1911), “Corporate Personality,” Harvard Law Review, 24(4): 253 267 and 24(5): 347-365.

MacMillan, Keith and Farmer, David (1979), "Redefining the Boundaries of the Firm," Journal of Industrial Economics, 27(3): 277-285.

Maitland, Frederick W. (1900), “The Corporation Sole,” Law Quarterly Review, 16(3): 335-354.

Maitland, Frederick W. (1903), “The Unincorporated Body,” in Fischer, H. L. A. (1911) (ed.), The Collected Papers of Frederick William Maitland, vol. 3, Cambridge: Cambridge University Press.

Maitland, Frederick W. (1905), "Moral Personality and Legal Personality,” Journal of the Society of Comparative Legislation, 6(2), 192-200.

Mäki, Uskali (2001), “Economic Ontology: What? Why? How?” in Mäki, Uskali (ed.), The Economic World View: Studies in the Ontology of Economics, Cambridge: Cambridge University Press.

Mark, Gregory A. (1987), "The Personification of the Business Corporation in American Law," University of Chicago Law Review, 54(4): 1441-1483.

Millon, David (1990), “Theories of the Corporation,” Duke Law Journal, 1990(2): 201262.

Moore, John (1992), "The Firm as a Collection of Assets," European Economic Review, 36(2-3): 493-507. 
Morawetz, Victor (1882), A Treatise on the Law of Private Corporations Other Than Charitable, Boston, MA: Little, Brown.

Nonaka, Ikujiro, Toyama, Ryoko and Nagata, Akiya (2000), “A Firm as a KnowledgeCreating Entity: A New Perspective on the Theory of the Firm," Industrial and Corporate Change, 9(1): 1-20.

Orts, Eric W. (1998), "Shirking and Sharking: A Legal Theory of the Firm," Yale Law and Policy Review, 16(2): 265-329.

Pettit, Philip (2003), "Groups with Minds of their Own,” in Schmitt, Frederick (ed.), Socializing Metaphysics: The Nature of Social Reality, Lanham, MD: Rowwan \& Littlefield.

Phillips, Michael J. (1994), "Reappraising the Real Entity Theory of the Corporation," Florida State University Law Review, 21(4): 1061-1122.

Raby, William L. (1959), “The Two Faces of Accounting,” Accounting Review, 34(3): $452-461$.

Radin, Max (1932), “The Endless Problem of Corporate Personality,” Columbia Law Review, 32(4): 643-667.

Ribstein, Larry E. (2003), "Making Sense of Entity Rationalization,” Business Lawyer, 58(3): 1023-1042.

Rowley, Scott (1931), “The Individuality of Business Associations," Virginia Law Review, 17(6): 557-569.

Ruben, David-Hillel (1983), "Social Wholes and Parts," Mind, 92(366): 219-238.

Searle, John R. (1995), The Construction of Social Reality, New York: Free Press.

Simon, Herbert A. (1991), “Organizations and Markets,” Journal of Economic Perspectives, 5(2): 25-44. Reprinted in this volume.

Simon, Herbert A. (1996), The Sciences of the Artificial, $3^{\text {rd }}$ edition, Cambridge, MA: MIT Press.

Simon, Herbert A. (2002), "We and They: The Human Urge to Identify with Groups," Industrial and Corporate Change, 11(3): 607-610. 
Singleton, W. E. (1912), "Entities and Real and Artificial Persons," Journal of the Society of Comparative Legislation, 12(2): 291-298.

Smith, Thomas A. (2001), "The Use and Abuse of Corporate Personality," Stanford Agora, 2(1): 69-72.

Stauss, James H. (1944), “The Entrepreneur: The Firm,” Journal of Political Economy, 52(2): 112-127. Reprinted in this volume.

Swanson, Guy E. (1992), "Doing Things Together: Some Basic Forms of Agency and Structure in Collective Action and Some Explanations," Social Psychology Quarterly, 55(2): 94-117.

Stout, Lynn A. (2005), “On the Nature of Corporations," University of Illinois Law Review, 2005(1): 253-267.

Teubner, Gunther (1988), "Enterprise Corporatism: New Industrial Policy and the 'Essence' of the Legal Person," American Journal of Comparative Law, 36(1): 130-155.

Thomasson, Amie L. (2003), "Realism and Human Kinds," Philosophy and Phenomenological Research, 67(3): 580-609.

Tuomela, Raimo (1989), “Actions by Collectives," Philosophical Perspectives, 3: 471496.

Vining, Joseph (1978), Legal Identity: The Coming of Age of Public Law, New Haven, CT: Yale University Press.

Weissman, David (2000), A Social Ontology, New Haven, CT: Yale University Press. Williamson, Oliver E. (1991), "Comparative Economic Organization: The Analysis of Discrete Structural Forms," Administrative Science Quarterly, 36(2): 269-296.

Williamson, Oliver E. (1999), "Strategy Research: Governance and Competence Perspectives," Strategic Management Journal, 20(12): 1098-1108.

Wimsatt, William C. (1997), “Aggregativity: Reductive Heuristics for Finding Emergence," Philosophy of Science, 54(S): S372-S384.

Wormser, I. Maurice (1912), "Piercing the Veil of Corporate Entity," Columbia Law Review, 12(6): 496-518. 
Zingales, Luigi (2000), “In Search of New Foundations," Journal of Finance, 55(4): 1623-1653. 


\section{NOTES}

${ }^{1}$ U. Lyon 2, LEFI \& INSA de Lyon, STOICA. david.gindis@univ-lyon2.fr. I would like to thank Yuri Biondi, Jan Dejnožka and Geoffrey Hodgson for their valuable comments on previous versions of this essay. All remaining errors and shortcomings are my own.

${ }^{2}$ A point of view also adopted by Friedman (1970) and restated recently by Jensen (2002). Buchanan (1988: 136) thus reminds us that "the values or interests of individuals are the only values that matter for the quite simple reason that these are the only values that exist."

${ }^{3}$ Given that the contractual association is voluntary, the firm has nothing to do with state grants or statutes. Summing up this position, Butler and Ribstein (1989: 768) celebrate the fact that "market forces have long since freed the corporation from the control of state legislators, and the corporation can now safely be viewed as fundamentally contractual." Easterbrook and Fischel (1991) and countless other private ordering proponents also hold this anti-regulatory view. In this chapter, we ignore this normative issue and focus on the ontological commitments of the contractual theory only.

${ }^{4}$ For detailed presentations of the corporate entity debate in the U.S. context, see Mark (1987), Hovenkamp (1988), Bratton (1989b), Hager (1989), Blumberg (1990a), Millon (1990), Horwitz (1992), Phillips (1994), Iwai (1999) and Avi-Yonah and Sivan (this volume). See Teubner (1988) for a general comparative approach and Foster (2000) for a comparison between England and France. For detailed historical accounts of business economics and entity theory debates both on the Continent and in the New World, see Canziani and Kirat in this volume. 
${ }^{5}$ In this chapter, we ignore the "concession theory of the corporation" and the question of state involvement and focus on the "fiction vs. reality" and "aggregate vs. entity" issues only.

${ }^{6}$ With the advent of LLCs, LLPs, LLLPs, and so forth, limited liability is no longer a unique characteristic of corporations and traditional differences between partnerships and corporations have become less obvious. One-man limited liability companies exist in many jurisdictions. Some jurisdictions allow various "check-the-box" schemes for setting up a business where one may literally choose a menu of items from different statutes if their combination is the most suited for the venture. We are not interested in these evolutions per se but in the shift of emphasis they provoke in the debate about "entity" status from corporations to all forms of business companies. In this context, some have expressed the need for a "unified business entity code" applying to all legal forms (e.g., Blackwell, 1999). Private ordering proponents such as Ribstein (2003) are of course very critical of these calls for "entity rationalization" since this could only be done through regulation.

${ }^{7}$ Strikingly, however, debates often center on the "sacred cow" of corporate existence (Israels, 1952). Litowitz (2005: 501) writes that "from the perspective of cultural theory ... the modern corporation is fundamentally a religious and mythological entity." We have before us a battle of the gods between "the corporation" and "the shareholders." A serious effort of "demystification" of the corporate entity is needed.

${ }^{8}$ See, in this volume, Rebérioux and Moore on entity theory and corporate governance, and Avi-Yonah and Sivan on entity theory and corporate social responsibility.

${ }^{9}$ Entity theories were themselves much criticized at the time. For instance, Singleton (1912: 291) considers that entity views are "ontological theories incapable of verification," Wormser (1912: 496) avoids the "tempting but profitless discussion," Radin (1932: 658) brushes off the debate as a "matter of literature" and Cohen (1935) speaks mockingly of "transcendental nonsense." The ontological individualists 
discussed in Section 2 are saying roughly the same thing as are aggregate theorists such as Morawetz (1882).

${ }^{10}$ Hart (2001: 1714) recognizes that "somehow there has to be some stickiness in the firm or system, so that a firm's reputation can be separated from that of key personnel." Hart's intuition is again correct although he does not provide an adequate theory of this stickiness.

11 This is quite different from the widely accepted thesis of "supervenience" which contains nothing in it to make it a necessary vertical relation (Humphreys, 1997). Even if applied to a vertical relation between levels, supervenience retains the ontological priority of the lower level: once the facts about the lower-level entities are set, so too are all the aggregate facts (Kincaid, 1995). There is still something missing from an ontological point of view. On the other hand, emergence is a failure of aggregativity (Wimsatt, 1997) and contains an explicit ontological commitment.

${ }^{12}$ Legally, firm members are certainly bound together since they share the common fate of the firm in the case of dissolution or absorption. Human asset specificity and knowledge and productive synergies are also by definition dependent on the firm's survival since their value is greater or only exists inside the firm. 